\title{
A CRIANC̣A E A INFÂNCIA SOB O OLHAR DA PROFESSORA DE EDUCAÇ̃̃O INFANTIL
}

Carla Tosatto*

Evelise Maria Labatut Portilho**

RESUMO: Este artigo tem origem na formação continuada de professoras de um Centro Municipal de Educação Infantil e apresenta a construção das seguintes unidades de significação: a criança como um ser naturalmente bom; a criança como um ser que vive na fantasia; a criança como um ser que brinca; a criança como um ser que aprende; e a criança como um ser que se desenvolve. Foi possível perceber que prevalece entre as professoras uma imagem idealizada, mitificada, naturalizada e homogênea da criança e da infância que tensiona as suas relações com as crianças na sua concretude. A criança como um ser que brinca ainda é vista de forma mais natural do que social, distanciando-se da concepção da criança como produtora de culturas próprias e singulares que precisam ser consideradas, ampliadas e ressignificadas.

Palavras-chave: Educação Infantil. Unidades de Significação. Formação Continuada.

\footnotetext{
* Psicóloga. Mestre em Educação pela Educação pela Pontifícia Universidade Católica do Paraná (PUCPR). Assessora da Área da Educação Infantil de Editora. Assessora Educacional da Rede Marista de Solidariedade. E-mail: ctosatto@uol.com.br

** Pedagoga. Especialista em Psicopedagogia, Grupos Operativos e Educação Especial. Mestre e Doutora em Educação. Professora Titular do Programa Stricto Sensu em Educação da PUCPR. Coordenadora do Grupo de Pesquisa Aprendizagem e Conhecimento na Prática Docente. Coordenadora do Curso de Especialização em Psicopedagogia da PUCPR. Conselheira e Coordenadora da Comissão de Formação da Associação Brasileira de Psicopedagogia (ABPp). E-mail: evelisep@onda.com.br
} 


\section{THE CHILD AND CHILDHOOD SEEN THROUGH THE CHILDREN EDUCATION TEACHERS VISION}

ABSTRACT: This article is based on the study reflection from teachers' continuing education who work in an Early Childhood Education Municipal Center. It presents the construction of meaning units supported by theoretical reference integration and interpretation of data at hand. The idea behind meaning units that were constructed is that children are inherently good; children are human beings who live in a fantasy world; children are human beings who learn; and children are human beings capable of development. It was observed that the prevailing mindset among teachers is an idealized, mythical, naturalized and homogeneous perception for both children and childhood, which is conducive to a tense relationship with children as they are. The child as a human being who plays is still the most natural rather than social perception, dissociating from the children concept as the generators of their own unique cultures that need to be taken into account, amplified and given new meaning.

Keywords: Early Childhood Education. Meaning Units. Continuing Education.

\section{INTRODUÇÃo}

O grupo de pesquisa Aprendizagem e Conbecimento na Ação Educativa', do Programa de Pós Graduação Strito Sensu em Educação da PUCPR, desenvolveu um projeto de formação continuada com professoras de Educação Infantil. O presente artigo faz parte de uma das pesquisas deste grupo, cujo objetivo foi conhecer os significados que as professoras de uma escola de Educação Infantil da Prefeitura Municipal de Curitiba atribuem à criança e à infância, assim como analisar a relação desses significados com a prática pedagógica desenvolvida na escola, para, com isso, refletir acerca do lugar que a criança ocupa nesse contexto.

Para este texto, foi destacada a construção das unidades de significação, realizada com base na integração entre o referencial teórico e a interpretação dos dados da pesquisa. Essas unidades de significação traduzem a forma como as crianças são concebidas no interior desta instituição escolar.

Essa temática vem sendo alvo da reflexão dos chamados estudos da infância, os quais destacam que a forma como a professora vê a criança reflete no lugar que ela ocupa na escola, nas práticas que são desenvolvidas para promover a sua aprendizagem. 
Ao refletir sobre o conjunto dos dados obtidos a partir dos instrumentos utilizados, foi possível dar visibilidade às narrativas das professoras sobre a criança e a infância, buscando, em suas falas e ações, vestígios, traços e retratos que respondessem às perguntas que nortearam a elaboração dessa pesquisa: Quais os significados que as professoras atribuem à criança e à infância? Qual a relação entre esses significados construídos pelas professoras e a prática pedagógica desenvolvida na escola? Que lugar a criança ocupa no interior da escola pesquisada?

Percebe-se, no contato com professores que atuam na Educação Infantil, que as respostas a essas questões mudam, dependendo da concepção que se tem delas, e essas concepções orientam práticas e ações que lhe são dirigidas. Segundo Pinto (1997, p.33):

Quem quer que se ocupe com a análise das concepções de criança que subjazem quer ao discurso comum quer à produção científica centrada no mundo infantil, rapidamente se dará conta de uma grande disparidade de posições. Uns valorizam aquilo que a criança já é e a faz ser, de fato, uma criança; outros, pelo contrário, enfatizam o que lhe falta e o que ela poderá (ou deverá) vir a ser. Uns insistem na importância da iniciação ao mundo adulto; outros defendem a necessidade da proteção face a esse mundo. Uns encaram a criança como um agente de competências e capacidades; outros realçam aquilo de que ela carece.

Enfim, concepções, significados e imagens diferentes compõem a visão dos professores que trabalham com as crianças, e esses olhares, certamente, determinam modos de atuação e possibilidades de trabalho com os pequenos. Assim, há diferenças entre as ações de um professor que concebe a criança como um ser incompleto - que ainda não sabe, não pode, não faz, mas que está sendo preparada para ser, saber e fazer - daquele que, por exemplo, acredita verdadeiramente na potencialidade das crianças e as vê como alguém que já sabe, pode e faz com competência muitas coisas; alguém que se utiliza de linguagens criativas e inovadoras para compreender e dialogar com o mundo.

O cotidiano da Educação Infantil é, portanto, marcado pela visão que os professores têm sobre as crianças, e isso se revela nas sutilezas das práticas, na organização do espaço e do tempo, nas propostas, nas interações e experiências possíveis, nas vozes que se manifestam e que se silenciam.

Assim, destaca-se a importância de favorecer, nos professores, a possibilidade de refletir sobre a concepção que possuem acerca da criança e da infância, a fim de provocar novos olhares, novas interações, novas ações. É preciso romper com algumas "certezas" construídas 
sobre o que é a criança e a infância e contribuir para a construção de novos olhares, novas imagens e concepções sobre esses atores sociais.

\section{METODOLOGIA DA PESQUISA}

O delineamento metodológico escolhido para as devidas aproximações ao problema da presente pesquisa foi o estudo qualitativo, ressaltando seu caráter compreensivo e interpretativo. E como referencial teórico-metodológico, adotamos a perspectiva da hermenêutica, tendo em vista seu caráter interpretativo e de construção de significados na esfera da linguagem.

$\mathrm{Na}$ proposta da formação continuada, foram realizados sete encontros reflexivos quinzenais com 32 professoras de um centro Municipal de Educação Infantil (CMEI). As participantes são nomeadas por P1, P2, P3 etc.

Escutar as professoras, as suas narrativas sobre a criança e a infância, observar suas ações, perscrutar os significados ali presentes foi um imenso desafio, instaurado por meio da imersão na realidade pesquisada. Disso decorre o uso da entrevista como aporte principal deste estudo, acompanhado das observações do ambiente educativo, considerado, nesta investigação, como a sala de aula e todo o espaço da escola pesquisada. Foi utilizado também o registro dos sete encontros reflexivos cuja intenção primordial foi a de colocar as professoras como protagonistas no ato de narrar suas experiências, seus questionamentos, suas histórias.

Cruzar informações por meio do uso destes instrumentos permitiu explicar e interpretar o que converge, analisar o que se contrapõe, perceber as idiossincrasias, enfim, favoreceu a instauração de um olhar de vários ângulos e de outras perspectivas.

Para a interpretação dos dados, foram criadas categorias, denominadas neste estudo unidades de significação. A organização e interpretação dos dados em unidades de significação correspondem a teias de sentidos acerca das concepções de criança e infância identificadas nas falas e ações das professoras.

É possível afirmar que, de cada unidade de significaçã, depreende-se uma imagem predominante de criança e infância. A seguir, apresenta-se esse "caleidoscópio de imagens" das quais emergem múltiplos significados. Vale ressaltar que essas imagens interpenetram-se, relacionam-se e influenciam-se mutuamente. É importante realçar, também, que elas coexistem e se sobrepõem, às vezes de modo conflituoso e tenso, outras vezes, de modo sincrético nas visões das professoras. 


\section{CRUZANDO OLHARES, SABERES E PRÁTICAS}

Ao buscar conhecer os significados atribuídos pelas professoras à criança e à infância, foram construídas cinco unidades de significação.

\section{A criança como um ser naturalmente bom}

A imagem da criança como um ser puro, ingênuo, feliz e naturalmente bom se encontra muito presente nos discursos das professoras dessa escola. A criança é tida como um ser bom por natureza, e a infância é narrada como um tempo mágico, só de alegrias, um paraíso. Isso pode ser corroborado pelas falas dessas professoras:

É a pureza, é o momento mais mágico da nossa vida. A infância é um momento de pureza, de inocência, é um momento de descoberta, um momento único e que deve ser aproveitado ao máximo. (P9)

Ai se eu pudesse voltar! Ser criança é magia, inocência, pureza, imaginação. (P 24)

As professoras definem a criança como um ser inocente e puro que está vivendo uma fase dourada e mágica da vida. Podemos inferir que o olhar das professoras se mostra bastante impregnado e influenciado pelas ideias dos chamados pedagogos românticos (Rousseau, Pestalozzi, Froebel), que exaltaram a criança como portadora de uma natureza essencialmente boa, que precisava ser preservada.

De acordo com Rousseau (1979), se a criança nasce "certa nas mãos do Autor das coisas”, o papel do educador é respeitar tal natureza, fazendo todo o esforço possível para que ela não sofra interferência ou intervenção em seu desabrochar. Tem-se aqui a ideia de que a criança nasce boa e a sociedade a corrompe. A infância seria o tempo da inocência, da pureza, da ingenuidade, da verdade e da bondade. A imagem predominante entre as professoras está, portanto, calcada nas concepções romântico-naturalistas que veem a criança como um ser puro e inocente que deve ser protegido da realidade.

Num dos encontros reflexivos, as professoras tinham como "tarefa" levar algo que representasse a concepção de criança e infância delas e justificar para o grupo a sua escolha. De modo geral, as escolhas das professoras e suas narrativas, voltaram-se para essa imagem idílica e romanceada da criança e da infância. Como exemplos, podemos citar as falas dessas professoras:

Eu trouxe o Pica-pau, pois é uma referência de desenho que en gostava muito de assistir. Hoje eu consigo ver que o Pica-pau é maldoso. Quando eu era criança, não. A criança não percebe isso, ela é ingênua. Criança para mim é isso, essa purez̧a. (P 29) 
Eu trouxe o Dumbo, um personagem do Walt Disney, porque marcou minha infância e porque traz a ideia da inocência, da bondade e da fantasia, que é como eu vejo a criança. (P 27)

É possível perceber nessas narrativas que ser criança significa ser portadora de algumas características inerentes a uma "natureza infantil”. Essas características seriam próprias da infância e se perderiam com o tempo, ou seja, com o crescimento (o se tornar adulto). Sendo assim, conforme a criança vai deixando de ser criança, ela perderia essa pureza, essa inocência, essa capacidade de ser "verdadeira". Concordamos com Dahlberg, Moss e Pence (2003, p.66) quando eles destacam que:

Esta é a criança de Rousseau, refletindo a sua ideia da infância como o período inocente da vida de uma pessoa - os anos dourados - e a crença de que a capacidade de autorregulação e o inato da criança vão buscar a Virtude, a Verdade e a Beleza; é a sociedade que corrompe a bondade com a qual todas as crianças nascem.

Portanto, ao apontarem para uma natureza boa e pura das crianças, as professoras reproduzem um discurso altamente idealizado acerca da infância, que vem dominando e influenciando há muito tempo os imaginários da docência. No entanto, essa visão idealizada vem se chocando com outras, as quais colocam em "cheque" essa imagem tão pura e cândida das crianças. Isso pode ser constatado nas falas de algumas professoras ao dizerem que as crianças eram boas, ingênuas e puras; mas que, na atualidade, elas não são mais assim, pois revelam outras características, como falta de respeito, de "educação" e de limites.

Notamos aqui o surgimento de uma imagem da criança que podemos chamar de criança sem limite, ou seja, uma criança que não aceita regras, não respeita os adultos, não é tão ingênua, tão inocente, tão "boa". Podemos perceber tal paradoxo, nas falas destas professoras:

Tempos atrás, eu definiria como um ser frágil, altamente pronta para aprender, tinha um horizonte amplo. Hoje, vejo que as crianças não têm limites, têm muita falta de respeito. (P 17)

Hoje tem muita criança bagunceira, endiabrada, hiperativa. Acho que elas estão tendo muita informação e não estão sabendo lidar com isso. E nós temos que dar conta. (P 13)

Miguel Arroyo (2004) vem chamando a atenção para essa tensão, enfatizando que os professores não estão conseguindo mais "encaixar" seus alunos nessas imagens idealizadas e historicamente construídas. Vale aqui realçar as palavras ditas por esse autor (2004, p.37): 
Idealizamos a infância e sua educação. As metáforas de beleza, flor, bondade e generosidade nos parecem por séculos as mais apropriadas. É compreensível que agora nos estranhamos: não vivemos mais cercados pela beleza, nem pela bondade. As escolas deixaram de ser jardim de infância e nós deixamos de ser jardineiros. A realidade social e moral da infância-adolescência tensiona nossas metáforas. Revela contradições incômodas.

As imagens sociais da infância são uma produção social e cultural que vem de longe e da qual a pedagogia e a docência se alimentam. As professoras dessa escola revelam, em suas narrativas sobre a criança e a infância, que a imagem de um ser ingênuo, dócil, bom por natureza, fácil de lidar e manipular está muito impregnada em seus imaginários, tensionando as relações com as crianças e as infâncias reais.

Isso denota a dificuldade das professoras em ver as crianças como atores sociais que sofrem as influências das suas condições concretas de existência, ou seja, das relações sociais, culturais, econômicas, familiares etc., nas quais vivem e constroem a sua infância. O olhar ainda está fortemente marcado pela ideia da existência de uma suposta natureza infantil, e não na ideia de condição infantil (CHARLOT, 1986). Podemos dizer que as professoras abstraem a diversidade e a pluralidade, enfatizando sobremaneira os traços comuns, alimentando, no imaginário social da escola e em seus próprios imaginários, uma imagem da criança pura e boa e da infância como a "idade de ouro".

\section{A criança como um ser que vive na fantasia}

A imagem da criança como um ser que vive na fantasia envolve duas questões cruciais: por um lado, as professoras apontam a importância da imaginação e da fantasia na vida das crianças, destacando que essa é uma característica própria da infância.

No entanto, a fantasia é concebida pelas professoras como uma forma de afastamento e isolamento do mundo, ou seja, ao fantasiar, a criança se alienaria e se distanciaria da realidade. Tal concepção pode ser ilustrada na narrativa destacada a seguir:

Ser criança é ser pura. A criança é muito pura. Ela não consegue ver o mundo como nós adultos. Eles fantasiam, conseguem fantasiar [...]. A criança é muito pura. Eu ainda acredito nessa criança que é criança, que não tem malícia. (P 21)

A imagem da criança como um ser que vive na fantasia referese a um ser isolado das influências do mundo. A fantasia, na visão das professoras, provoca o distanciamento da realidade, não sendo 
concebida como possibilidade de compreensão, inserção e diálogo da criança com o mundo. Ela afasta e, com isso, protege a criança desse mundo "duro" e "cruel" dos adultos. Essa imagem está intimamente ligada com a visão idealizada e romântica de criança e infância destacada anteriormente.

Isso se contrapõe à concepção de imaginação e fantasia apontada por Vygotsky (2009). Ele questiona a fronteira comumente estabelecida entre fantasia e realidade e/ou entre imaginação e conhecimento, destacando que o limite entre a esfera do real e a do imaginário é altamente permeável, ocorrendo movimentos dialéticos constantes, de mútuas implicações.

A fantasia não paira acima do real, não se desconecta do mundo, não se aprisiona num lugar suspenso e oposto ao da realidade. Ao contrário, ela ajuda a compor, recompor, criar e recriar o real.

Sarmento (2004) também fala, ao abordar as gramáticas da cultura infantil, sobre a fantasia do real. Ele destaca que o "mundo do faz de conta" faz parte da construção da visão de mundo da criança e da sua atribuição do significado às coisas. Na fantasia, o real é interpretado e transformado pela criança, o que faz parte de sua experiência enquanto reprodutora e produtora de cultura. Portanto essa ação revela sua capacidade de criação e invenção, mas uma criação e invenção que estabelece um diálogo com o real, que se nutre das interações com o mundo, com a cultura, com as outras crianças, com os adultos, enfim, que se estabelece no plano das interações e não do isolamento.

Ao brincar, a criança dá uma nova ordem às coisas, trazendo simultaneamente o vivido e o novo, construindo cultura, refletindo e refratando a realidade na qual está inserida. Vale aqui realçar as palavras ditas por Sarmento (2004, p.16), quando ele enfatiza que "a dicotomia realidade-fantasia é demasiado frágil para denotar o processo de imbricação entre dois universos de referência, que nas culturas infantis efetivamente se encontram associados".

$\mathrm{Na}$ concepção das professoras, a capacidade de imaginar das crianças pouco se vincula à ideia de uma inserção ativa e criativa delas no real; é mais de um isolamento e de um ato de rompimento com o real que se trata. Essa imagem da criança que fantasia e, ao fantasiar, distancia-se da realidade, está diretamente ligada à ideia da concepção do brincar como algo natural, neutro, desinteressado e parte da "essência" infantil. Por isso mesmo, o ato de fantasiar e imaginar é visto como desvinculado do contexto social. Ao brincar, ao fazer de conta, ao fantasiar, as crianças ficariam isoladas das influências do mundo, suspensas e protegidas da realidade. 
Vale destacar que algumas professoras colocaram que as crianças estão sendo "inseridas no real" precocemente e, por isso, "perdendo a fantasia", a inocência, a possibilidade de viver esse "mundo mágico" da infância. Essa visão não deixa de ser igualmente polarizadora, colocando o real de um lado e a fantasia de outro. Ser criança é viver na fantasia, e as crianças estão deixando de ser crianças por não estarem vivenciando esse "mundo mágico da fantasia". Algumas professoras destacaram que as crianças estão sendo muito cobradas e "deixando de ser crianças" muito cedo, como na fala de P 21.

Como hoje muitos pais direm: Ab! Não tem Papai Noel, não tem Coelhinho da Páscoa. Mas, se você for olhar bem no fundinho da criança, ela ainda acredita. Então, en acho que o adulto está tražendo pra criança a realidade, muita informação [...].A criança está perdendo assim a magia. (P 21)

Portanto, foi possível perceber que essa fantasia não se relaciona com a força imaginativa, criativa e interpretativa da criança diante do mundo, mas sim, com sua inocência, fragilidade e pureza; com a capacidade da criança em acreditar naquilo que "não é real" e, portanto, é belo, puro, mágico, próprio da infância romantizada e idealizada que foi a tônica dos discursos das professoras. Não se observa aqui a importância da fantasia como forma de lidar, interpretar, inserir-se, compreender, criar e recriar a realidade!

\section{A criança como um ser que brinca}

Em muitas das falas das professoras, a criança foi narrada como um ser que brinca, sendo essa ação apontada como uma característica própria da criança e da infância, importante para o seu desenvolvimento e aprendizagem. Isso pode ser percebido na fala desta professora:

Brincar bastante. Eu acho que a criança aprende muito brincando. Não é por um trabalho pesado que a criança vai aprender. Na brincadeira, eles também estão aprendendo. (P 5)

Podemos inferir que a concepção de que a criança "aprende brincando" está bastante impregnada nos discursos das professoras, pois, além das falas destacadas, muitas apontaram a brincadeira como "coisa de criança" e como uma ação que precisa estar presente na escola para favorecer a aprendizagem de seus alunos. No entanto, percebe-se que se trata de um discurso pronto, da "moda", um "jargão pedagógico". Concordamos com Alarcão (2003), quando ela destaca que, muitas vezes, na arena educativa, 
emergem ideias novas ou renovadas que catalisam, contagiam, mas que se transformam, muitas vezes, em slogans, que só ao serem pronunciados seriam autoexplicativos.

Essa conclusão parte da premissa de que, ao falar da criança e da infância, o brincar se incorporava naturalmente na narrativa das professoras. No entanto, de uma forma acrítica e não reflexiva, ou seja, percebemos que se tratava de um discurso pronto, provavelmente advindo de cursos, palestras, da própria orientação da coordenação pedagógica da escola, mas não de uma práxis que concebe o brincar como experiência de cultura das crianças, como uma ação que implica a leitura, a compreensão e a transformação do mundo.

Está muito presente ainda, nas professoras, a ideia da brincadeira natural, própria de uma essência, de uma natureza, algo que vem de dentro da criança, que nasce com ela. Isso se reflete na imagem da criança como um ser naturalmente bom, bem como na imagem da criança como um ser que vive na fantasia, ou seja, nas visões românticas e idílicas da criança, destacadas anteriormente. A essa imagem da criança pura e boa estende-se a da criança que brinca, sendo essa uma ação apontada como própria e natural da infância e não como uma ação própria da cultura infantil, na qual a criança revela sua capacidade não só de reprodução, mas de interpretação e recriação de si mesma e do mundo que a cerca.

A forma como as professoras concebem a brincadeira ainda está longe da ideia do brincar como uma atividade social e cultural, bem como da imagem da criança produtora de identidade, conhecimento e cultura. Não há uma relação entre a criança que brinca e que, ao brincar, produz cultura ao interagir com seus pares, objetos, situações e realidades diversas.

Outro aspecto que se destacou em relação à ideia da criança como um ser que brinca é que a brincadeira, para poder se fazer presente na escola, precisa ter sempre uma "intenção didática". Essa intenção didática, na fala e nas ações das professoras, significa que a brincadeira precisa ser usada para ensinar algo, que quase sempre é um conteúdo específico: números, letras, cores, tamanhos etc. Podemos identificar isso nas falas das professoras:

São as atividades lúdicas direcionadas. Então tem que fazer um bom planejamento, deve buscar atividades dentro da faixa etária deles e estar trabalhando sempre. Através da ludicidade é que eles vão se desenvolver. (P 9)

Então, eu acho que é bastante do desenvolvimento motor, bastante de percepção visual e auditiva, se já está reconhecendo as cores, as formas. Claro, tudo isso desenvolvido de forma bem lúdica. (P 10) 
Sabemos da importância da intencionalidade nas ações educativas e que o uso do brincar na escola deve estar revestido de intenções e significados construídos pelas professoras, os quais são orientadores do planejar e do participar do brincar das crianças na escola. Uma intenção que valorize o brincar e que reconheça sua dimensão criadora, cultural e social é, pois, fundamental.

No entanto, neste cenário, a ideia de uma "intenção didática" se reveste de motivo maior para o uso do jogo, transformando-o numa atividade mecânica, dirigida e controlada pelas ações da professora que ensina (passa conhecimento) e das crianças que aprendem (recebem o conhecimento).

Isso pôde ser percebido nas observações realizadas em sala de aula, pois foi possível analisar como o brincar era incorporado ao cotidiano da escola pesquisada e com que objetivos. O brincar sempre era inserido de forma direcionada pela professora, que determinava tudo, e a criança tinha pouco espaço para ser autora da brincadeira.

O que vislumbramos é o brincar revestido de aula, engolido pelo tempo e sem a participação criativa, inventiva e transformadora das crianças. Um brincar que não se abre para a manifestação das culturas da infância!

Vale lembrar que a ludicidade, a fantasia do real, a interatividade e a reiteração são os eixos estruturantes apontados por Sarmento (2004), que caracterizam as culturas da infância, pois as crianças possuem modos diferenciados, genuínos e próprios de interpretar, simbolizar e comunicar sua percepção e conhecimento do mundo. Ele destaca, também, que a natureza interativa do brincar das crianças constitui-se como um dos primeiros elementos fundacionais das culturas da infância. Para ele, o brincar é a condição da aprendizagem e, desde logo, da aprendizagem da sociabilidade. No brincar, a criança é (ou deveria ser) protagonista de sua ação. É a criança que brinca e, ao brincar, reapresenta e ressignifica o que vive, sente, pensa e faz.

Em função de uma rotina rígida e controlada de forma exacerbada pelo tempo cronológico, linear e fragmentado, sem espaço para vivências e experiências compartilhadas, a criança como um ser que brinca, na verdade, brinca muito pouco nessa escola. O brincar não se configura num espaço de produção cultural, de autoria, de invenção e diálogo com o mundo, mas, sim, de controle, de "ensino", onde predomina a instrução do professor e não as linguagens e produções simbólicas das crianças.

As professoras estão muito apegadas às rotinas e às atividades de cunho mais tradicional, não conseguindo ver a criança na sua poesia e na sua forma metafórica de significar o mundo. 


\section{A criança como um ser que aprende}

A criança foi frequentemente narrada como um ser que aprende, ou seja, as professoras reconhecem o tempo da infância como um tempo de muitas descobertas, muitas aprendizagens. Para realçar essa imagem, podemos destacar as falas destas professoras, ao responderem às questões 6 e 7 da entrevista:

A criança é mais aberta ao aprendizado. Elas aceitam tudo. Então, tem que tomar cuidado, se policiar com o que você fa\%. Porque elas estão abertas a tudo. (P 4)

Nossa, é difícil né, ser criança né, acho que é estar aberto pro mundo, é um ser aberto pro mundo, ele recebe o que o mundo está ali oferecendo pra ele. Então ser criança é estar aberto pro mundo mesmo! É o comecinho, né? Ele está começando a entender as coisas, a assimilar e a fazer todas as coisas. (P 29)

Pelas falas destacadas, depreende-se que "aprender" se configura em receber, de forma mais verticalizada e impositiva, valores e conhecimentos dos adultos. A imagem é a da professora que ensina (passa valores, informações, conhecimentos) e a da criança que aprende (recebe, absorve esses valores, essas informações e conhecimentos), sendo esse processo unidirecional e calcado na transmissão e na instrução. Destacam-se aqui as palavras usadas pelas professoras ao falarem dessa criança como um ser que aprende: "colocar, jogar ali dentro, mostrar o caminho correto, dar uma lição, absorver, receber, assimilar, entender". Certamente são palavras inundadas de sentidos, os quais são reveladores do modo de interagir e, portanto, de "ensinar" das professoras.

Sarmento (2007) destaca que as crianças foram pensadas prioritariamente como objetos ou destinatários de processos de socialização, pelos quais as gerações mais novas adquirem normas, valores, crenças e ideias do seu grupo social de pertença, sendo introduzidas à reprodução social. Essa parece ser a visão das professoras, pois tanto a socialização quanto a aprendizagem das crianças são percebidas como tendo uma via de mão única e, não, como uma relação recíproca, na qual as crianças também interferem. Portanto, um sabe (professora) e outro não sabe (criança) e há algo "correto" a ser transmitido.

Não há, por parte das professoras, a compreensão das crianças como atores sociais e autores capazes de modificar e criar culturas, embora inseridas, influenciadas e atreladas à cultura dos adultos. A criança é vista como objeto "menor", signo de incompletude e dependência do ponto de vista tanto cognitivo quanto moral. 
Isso se manifesta na prática desenvolvida na escola, pois, em geral, a criança ocupa um lugar mais passivo, que ativo; mais de reprodução do que de criação; mais de espera do que de iniciativa; mais de ouvir, do que de ser ouvida.

Para ampliar o olhar para essa questão, segue o trecho de uma observação realizada na turma maternal III (3 e 4 anos), na qual é possível perceber esse lugar ocupado pela criança, ou seja, o de mero aprendiz:

As crianças estão com a professora na Niceteca (biblioteca da escola). Ela tem um livro nas mãos e fala para as crianças ficarem em silêncio que ela vai contar uma história.

- Vou contar a história da Bruxa Salomé. É esta bruxa que está esperando os chapéus ficarem prontos.

A professora contou a história para as crianças que se mostraram atentas, curiosas e interessadas. Ao final da leitura, as crianças começaram a ficar inquietas. A professora e a educadora pegaram nas mãos das crianças e foram caminhando para a sala de aula. $\mathrm{Na}$ sala, as crianças sentaram em seus lugares e a professora falou:

- Agora vocês vão desenhar a Bruxa Salomé.

(Vale destacar que antes das crianças irem para a biblioteca, a professora fez uma atividade na qual elas tinham que enfeitar um chapéu com as cores verde, amarelo e azul, pois estavam "comemorando" o dia da independência do Brasil. Ao "propor" a atividade para as crianças, ela fala que tem uma bruxa na escola chamada Peruqueira que está esperando o chapéu ficar pronto e se ela não gostar vai jogar tudo no caldeirão da bruxa. Depois de falar isso, a professora pergunta às crianças: vocês vão me ajudar a deixar o chapéu bonito? Ao ouvir isso, uma criança diz: e se ela não gostar do meu chapéu? É por isso que neste trecho da observação a professora fala que a bruxa Salomé (não mais a Peruqueira) é que estava esperando pelos chapéus).

(Observação realizada na turma das professoras 9 e 30. .)

A professora faz a leitura de uma história para as crianças. Ao terminar a leitura, ela não estabelece um diálogo com as crianças, não se dispõe a ouvir os comentários sobre a história, as possíveis interpretações e sentidos construídos. Ler a história se configurou apenas num motivo para realizar uma atividade - o desenho. O mais significativo nessa situação é que, quando a professora pede que as crianças façam o desenho, ela já diz o que elas devem desenhar, ou seja: "Agora vocês vão desenhar a Bruxa Salomé" (fala da P 30).

É possível notar que, quando interagem com as crianças, as professoras tendem a determinar os sentidos das suas ações, a antecipar respostas, ideias, movimentos, atropelando os sentidos 
que as próprias crianças podem e precisam construir. Concordamos com Dahlberg, Pence e Moss (2003, p.75) quando asseveram que:

As construções da infância e das crianças são produtos da prática; em outras palavras, o trabalho pedagógico é o produto de quem pensamos que a criança seja. A construção da criança como um vaso vazio ou como um reprodutor dá origem a uma ideia da pedagogia ou da educação como um meio de transmitir à criança, ou depositar nela, um corpo predeterminado e inquestionável de conhecimento, com um significado pré-fabricado.

As profissionais esboçam, portanto, uma prática que finca raízes na abordagem tradicional de ensino, para a qual a criança é passiva, cabendo à educação discipliná-la e inculcar-lhes regras, por meio da intervenção direta do adulto e da constante transmissão de modelos.

A imagem da criança como um ser que aprende se relaciona, por conseguinte, com as imagens mais tradicionais da criança: a de um ser passivo, heterônomo, frágil, submisso, dependente, imaturo e em processo de socialização, ou seja, a imagem da criança como um objeto passivo de um processo de socialização regido por instituições (escola, família, religião).

Assim, podemos dizer que a imagem da criança como um ser que aprende está fortemente impregnada pela visão do "ofício de aluno", ou seja, pela imagem da criança como aprendiz (reprodutor de cultura) e, não, pelo "ofício de criança", o que implica considerar, valorizar, ressignificar, ampliar as culturas infantis no interior da escola, favorecendo o diálogo e o entrelaçamento de culturas.

Ao proferirem em seus discursos a imagem da Educação Infantil como um período que "prepara para a aprendizagem", ou seja, como um tempo que não é importante em si mesmo, mas sim depois, quando os "frutos poderão ser colhidos", as professoras deixam transparecer a ideia de uma criança que também "vai ser", "vai aprender" e que "ainda não é". O futuro é mais importante que o presente. E, como escreveu Rosemberg (1985, p.25) "na sociedade centrada no adulto a criança não é. Ela é um vir a ser. Sua individualidade deixa de existir. Ela é potencialidade e promessa".

O período da infância é visto, portanto, como um treinamento para o futuro, como estágio preparatório, formativo, como um tempo de passagem.

\section{A criança como um ser em desenvolvimento}

Nas narrativas das professoras, destaca-se a visão da criança como um ser em desenvolvimento. Elas apontam o desenvolvimento como um processo no qual a criança passa por fases e, progressivamente, 
vai se tornando mais "madura”, mais "capaz". Isso pode ser ilustrado pelas falas destas professoras:

Através dos desenhos que eles fazem que comeca com a garatuja e vai tomando forma, vai passando as fases, a criança vai se desenvolvendo, o cérebro vai amadurecendo. É isso, é um ser em constante processo de desenvolvimento, através é claro, de um estimulo, mas se não tiver, eles mesmos vão se desenvolvendo e se tornando melhores, mais capazes. (P 25)

De uma forma geral é o desenvolvimento infantil mesmo, para a criança ir para as outras etapas, porque o maternal na verdade é o início, né? Então, você tem que fazer com que a criança conviva bem em grupo com os colegas, aprenda a respeitar regras básicas de convivência. Então, é mais o desenvolvimento. (P 19)

Se a criança é um ser em desenvolvimento, é preciso conhecer e favorecer esse desenvolvimento. Essa questão permeou o discurso das professoras que apontaram para a necessidade de conhecer as fases de desenvolvimento pelas quais as crianças passam, bem como o que esperar de cada fase. Podemos afirmar que, para as professoras, "conhecer a criança" é o mesmo que "conhecer o seu desenvolvimento", e o desenvolvimento é tido como uma sucessão de etapas/fases determinadas, pelas quais a criança necessariamente tem de passar e ultrapassar num tempo determinado.

Como escreveu Dahlberg, Pence e Moss (2003, p.63) "não existe algo como a criança ou a infância, um ser e um estado essencial esperando para ser descoberto, definido e entendido, de forma que possamos dizer a nós mesmos e aos outros o que as crianças são e o que a infância é". Porém foi possível constatar que a concepção de um desenvolvimento infantil homogêneo, universal e padronizado ainda se faz muito presente nas professoras dessa escola.

Isso confirma a hegemonia da produção científica que vem sendo produzida acerca das crianças, ou seja, as produções advindas da psicologia do desenvolvimento, as quais estão intimamente ligadas à imagem da criança naturalmente desenvolvida (JAMES; JENKS; PROUT, 1998). A criança é vista, portanto, como um ser que se desenvolve por meio de estágios universais e homogêneos e passa a ser olhada, analisada e comparada em função desse suposto desenvolvimento, o qual é sempre "esperado" dentro de um tempo e um período determinado.

Sarmento (2007) fala sobre as invisibilidades às quais as crianças foram e, muitas vezes, ainda são submetidas. Ele destaca a invisibilidade histórica e cívica, ambas decorrentes de uma invisibilidade científica. Essa invisibilidade científica não se refere à falta de estudos sobre a criança, mas, sim, ao tipo dominante de produção de conhecimento. 
Outra imagem que pode ser destacada aqui é a da criança normal, pois foi possível perceber, nas falas das professoras, uma redução das idiossincrasias individuais a determinados denominadores comuns, considerados critérios ou normas características da idade. Desse modo, a noção de criança normal apoia-se sobre um mecanismo de minimização das diferenças entre os sujeitos e maximização das semelhanças. De acordo com Mollo-Bouvier (2005, p. 398), "o advento da escolaridade obrigatória coincidiu com o desenvolvimento de uma psicologia orientada pela preocupação com uma observação científica da criança, que fixava as diferenças autorizadas em relação a uma normalidade tanto intelectual como social".

A infância é compreendida, portanto, como um período em que se sucedem fases de um modo linear e evolutivo, independentemente do contexto sociocultural no qual as crianças estão imersas. De modo geral, as professoras revelaram essa concepção, pois foram poucas as que destacaram o papel da educação e do contexto sociocultural nesse processo.

Está impregnada nos discursos das professoras a ideia de que é necessário "esperar" para ensinar, e o que vai determinar o que pode ser ensinado e o que a criança pode aprender é o seu "desenvolvimento". Um desenvolvimento visto de forma mais natural que social, mais homogêneo que diversificado, mais atrelado às idades e fases que às condições de vida e de aprendizagens propiciadas às crianças. Pode-se dizer que tais sentidos constituídos sobre as crianças estão atrelados a uma concepção naturalizante da infância e calcados na ideia de que as práticas educativas encerram em si certas impossibilidades, uma vez que a visão é de que a criança que não está pronta ainda é imatura.

Em consequência da ideia de que há um desenvolvimento padrão, normal e mais adequado a ser seguido e "perseguido", as professoras demonstram dificuldades em lidar com as diferenças. Segue um relato indicativo dessa proposição:

Mas, na sala de aula tem aquela coisa, respeita-se sim as diferenças, a gente procurar fazer um interagir com o outro, mas tem aquela expressão que en usei - tem que entrar no ritmo senão a coisa não funciona, não anda. Dai você vê que tem que ser todo mundo igual ou o mais parecido possivel. Tem que dar a mesma atividade para todo mundo, tem que fazer a mesma atividade para o grupo. (P 4)

Ao mesmo tempo em que a professora destaca que essa diferença existe e precisa ser levada em conta, coloca, também, que é preciso "entrar no ritmo", que tem de ser "todo mundo muito parecido", senão não dá para trabalhar, deixando transparecer a ideia de que a busca é por anular as diferenças e não por promovê- 
las. Não há a compreensão de que a heterogeneidade pode ser um rico potencial para trocas e aprendizagens compartilhadas. Promover a diferença é respeitar e fazer valer a alteridade e singularidade de cada um. Concordamos com Abramowicz (2011, p. 32) quando ela assevera que:

Precisamos no nosso trabalho cotidiano incorporar o discurso das diferenças não como um desvio, que é o lugar em que o diferente tem sido colocado, mas como o mote de nossas práticas e das relações entre as crianças. Essa seria uma postura que reclama novos afetos, uma nova forma de se relacionar com o diferente, com o estrangeiro, ou seja, com a diversidade, com o outro que não é mais um "mesmo" de mim.

Portanto, podemos dizer que a visão predominante das professoras em relação ao desenvolvimento está pautada na homogeneidade, na abstração das diferenças, na ideia de etapas que precisam ser vencidas num determinado tempo e na concepção de desenvolvimento como pré-requisito para o ensino e a aprendizagem das crianças.

Larrosa (2006) destaca que há diferentes olhares e formas de se relacionar com as crianças. Uma delas é quando olhamos para as crianças e vemos aquilo que já sabemos, e que vem dos saberes constituídos e dominantes, como os construídos pela psicologia, pela mídia e pela religião. Esse seria o "sujeito do reconhecimento". Outra forma seria se apropriar da criança, sem reconhecê-la, pois o adulto a transforma em algo à sua medida. Esse seria o "sujeito da apropriação". E por fim, o autor aponta um novo olhar para essa interação, a do "sujeito da experiência", que pressupõe o encontro com a criança e sua "eterna novidade" e possibilidade de reinvenção da vida.

\section{CONSIDERAC̣ÕES FINAIS}

Vale lembrar que as unidades de significação referem-se às imagens predominantes de criança e infância das professoras, constituindose numa teia de sentidos que se imbricam mutuamente, advindos de um contexto particular que se deixou desvelar pelos discursos e práticas de seus atores - professoras.

Esse "caleidoscópio de imagens" guarda entre si relações múltiplas, de convergências e divergências, de tensões e contradições, não sendo estanques, tampouco imutáveis. São produções simbólicas que se inserem num contexto social e histórico determinado. 
E, como toda construção social, está continuamente sendo tecida e transformada por seus atores.

Refletindo acerca dessas unidades de significaşão, podemos dizer que, de forma predominante, a criança foi concebida como um ser naturalmente bom. E esse ser natural, bondoso e ingênuo revelase na ideia de um ser menor, dócil, fácil de manipular e "ensinar". Subjaz aqui uma "infantilização" da criança e uma idealização acrítica e mitificada da infância.

Essa imagem idílica da infância origina paradoxos e contradições, que tensionam as relações das professoras com as crianças, oscilando entre a "verdadeira" ideia de criança e infância e sua "subversão", ou seja, entre uma criança idealizada, romanceada e mitificada, cuja imagem fundante e simbólica é a da pureza, da inocência, da ingenuidade e da verdade, e a das crianças em sua concretude, em suas múltiplas e diversas faces, condições e produções.

A criança como um ser que vive na fantasia coloca a criança e a infância em uma espécie de redoma que a protege e afasta do real, sendo essa a condição que lhe permite permanecer/ficar nessa infância mitificada, nessa fase dourada e mágica da vida. Portanto, uma ideia de fantasia que pouco se vincula à forma singular de inserção, diálogo e compreensão do mundo que a criança faz ao brincar, ao criar metáforas, ao inventar, ao transpor mundos, ao transver o real. Como escreveu Manoel de Barros, "O olho vê/ A lembrança revê/ E a imaginação transvê/ É preciso transver o mundo".

A criança como um ser que brinca deixa-se transparecer em um discurso estéril, ou seja, esse ser que brinca apareceu mais no discurso das professoras que em suas interações com as crianças, pois, nessas interações, o brincar foi transformado em "aula", numa "atividade" que pouco se assemelha ao poder de criar, conviver, dialogar, sentir e aprender que o "brincar de verdade" provoca e proporciona.

A criança como um serque aprende revela uma crença no potencial de aprendizagem das crianças, mas revela, igualmente, uma concepção de aprendizagem calcada na ideia de inculcação e transmissão, que, mais uma vez, "menoriza" e oculta a criança e seu protagonismo.

E a criança vista como um ser em desenvolvimento deixa transparecer um domínio ainda muito presente da "criança cientificizada", ou seja, explicada, teorizada, medida e avaliada segundo padrões preestabelecidos de desenvolvimento. Tal concepção mais delimita do que abre possibilidades, mais condiciona o olhar a ver o que falta na criança do que aquilo que ela é capaz de realizar, mais 
a sua fragilidade do que a sua potência. A criança não é vista em sua complexidade irredutível, sendo reduzida a manifestações de um pensamento ainda em construção.

Essas unidades de significação estão umbilicalmente ligadas, uma se imbrica na outra, desvelando crenças, ideias, concepções e estereótipos que ecoam e ressoam nas imagens que, tradicionalmente, vêm sendo imputadas à criança e à infância, as quais carregam a marca de uma concepção mais naturalizada, homogênea e idealizada do que uma visão historicizadora, cultural e social.

Essas imagens, predominantes nos olhares e fazeres das professoras, deixam transparecer a força dos discursos construídos acerca da criança e da infância, em especial dos discursos científicos, que vêm nomeando, explicando e determinando lugares, espaços e ações junto às crianças. Suas narrativas não deixam dúvidas: esses discursos ainda são hegemônicos e permanecem influenciando, sobremaneira, suas práticas e suas formas de interação com as crianças.

\section{REFERÊNCIAS}

ABRAMOMOWICZ, Anete. A pesquisa com crianças em infâncias e sociologia da infância. In: FARIA, Ana L. G.; FINCO, Daniela (Orgs.). Sociologia da infância no Brasil. Campinas, SP: Autores Associados, 2011. p.17-36. (Coleção Polêmicas do Nosso Tempo).

ALARCÃO, Isabel. Professores reflexivos em uma escola reflexiva. São Paulo: Cortez, 2003.

ARROYO, Miguel. Imagens quebradas: trajetórias e tempos de alunos e mestres. Petrópolis: Vozes, 2004.

CHARLOT, Bernard. A mistificação pedagógica: realidades sociais e processos ideológicos na teoria da educação. Rio de Janeiro: Zahar, 1986.

DAHLBERG, Gunilla; MOSS, Peter; PENCE, Alan. Qualidade na educação da primeira infância: perspectivas pós-modernas. Porto Alegre: Artmed, 2003.

JAMES, Allison; JENKS, Chris; PROUT, Alan. Theorizing childhood. Cambridge: Polity Press, 1998.

LARROSA, Jorge. Pedagogia profana: danças, piruetas e mascaradas. Belo Horizonte: Autêntica, 2006.

MOLLO-BOUVIER, Suzanne. Transformação dos modos de socialização das crianças: uma abordagem sociológica. Educação \& Sociedade, Campinas, v. 26, n. 91, p. 391-403, maio/ago. 2005.

PINTO, Manuel. A infância como construção social. In: PINTO, Manuel; SARMENTO, Manuel Jacinto. As crianças: contextos e identidades. Braga: Centro de Estudos da Criança/ Universidade do Minho - Portugal, 1997, p.31-73.

ROSEMBERG, Fúlvia. Literatura infantil e ideologia. São Paulo: Global, 1985.

ROUSSEAU, Jean-Jacques. Emílio ou da educação. Rio de Janeiro: Difusão, 1979. 
SARMENTO, Manuel Jacinto. As culturas da infância nas encruzilhadas da 2. ${ }^{a}$ modernidade. In: SARMENTO, Manuel Jacinto; CERISARA, Ana Beatriz (Orgs.). Crianças e miúdos: perspectivas sociopedagógicas sobre infância e educação. Porto: Asa, 2004, p.9-34.

. Visibilidade social e estudo da infância. In: VASCONCELLOS, Vera M. R.; SARMENTO, Manuel Jacinto. (Orgs). Infância (in) visivel. Araraquara, SP: Junqueira \& Marin, 2007, p.25-53.

VYGOTSKY, Lev S. A imaginação e a arte na infância. Lisboa: Relógio D’água, 2009.

\section{NOTAS}

${ }^{1}$ Pesquisa financiada pelo CNPQ e Fundação Araucária.

Recebido: 01/02/2013

Aprovado: 11/05/2014

Contato:

Pontifícia Universidade Católica do Paraná Departamento de Educacao. Rua Imaculada Conceicao, 1155 - Prado Velho Curitiba | PR | Brasil CEP 80.215-901 